\title{
A Sectoral Analysis of Poverty in Pakistan
}

\author{
MuHAmmad Ali BHATti, RASHIDA HaQ, and TARIQ JAVED
}

\section{INTRODUCTION}

Since independence, the problem of mass poverty in Pakistan has been substantial. The number of the destitute has continued to soar. The problem of poverty now looks to be beyond control. The vast masses of the people, particularly in rural areas, are indeed, miserably below the poverty line. Moreover, the socioeconomic and demographic indicators are dismal. Official planning and the market economy system have failed to lessen poverty. The policies formulated to eradicate it have failed to achieve their objectives.

The issue of poverty in Pakistan has its significance for sustainable development. Long run development is not possible without protecting the rights of the vulnerable groups and the participation of the entire population in the development process. Although Pakistan's economic growth has been quite respectable for much of the last four decades but it has failed to trickle down to the masses. The country has experienced poverty and stagnation in 1950s, increasing poverty and growth in the 1960s, stagnation of growth but declining poverty in the 1970 s, increasing growth and declining poverty in the 1980s and finally, increasing poverty and falling growth in the 1990s [MHCHD/UNDP (1999)].

The mainstream approach to identifying the poor specifies a cut-off point 'poverty line', defining the level of income/expenditure below which people are diagnosed as poor. The conventional measure of poverty, head-count index, has been widely used in Pakistan. However, in practice this absolute threshold usually cannot stand the pressures of changing circumstances and is not as absolute as the term would appear to imply [Zaidi and de Vos (1993)]. To show the true face of poverty this study uses Foster, Greer and Thorbecke (1984) class of additively decomposable measure to estimate the variation in the incidence, intensity and severity of poverty across sectors of employment. This study also determines the relative contribution of the various sectors to aggregate poverty. Location index is also used to measure the concentration of poor in each sector. To evaluate the sources of observed changes in sectoral poverty at the micro level 'HIES' data sets are used. The present paper is based on the Basic Needs Approach for the years 1987-88 and 1990-91.

The paper is organised in five sections. After the introduction, the inquiry will proceed as follows: Section 2 will start by providing trends of poverty in Pakistan.

Muhammad Ali Bhatti, Rashida Haq, and Tariq Javed are Assistant Professor at Gordon College, Rawalpindi, Research Economist at Pakistan Institute of Development Economics, Islamabad and Assistant Professor at Quaid-i-Azam University, Islamabad, respectively. 
Section 3 will establish the methodology, Section 4 empirical analysis and Section 5 will present some general conclusions.

\section{TRENDS OF POVERTY IN PAKISTAN}

The history of research studies on poverty and related issues in Pakistan is based on the following approaches:

(i) The Arbitrary Poverty Line.

(ii) The Minimum Calorie Requirement Approach.

(iii) The Basic Needs Approach.

(iv) The Subjective Approach.

(v) The Relative Poverty Approach.

The new concept of Human Poverty Index (HPI) and Poverty of Opportunity Index (POPI) have also been introduced in Pakistan.

The arbitrary poverty line is determined without attempting a justification. The earlier studies done by Naseem (1973) and Allaudin (1975), arbitrarily fixed poverty lines in terms of per capita expenditure and per capita income respectively. Both the studies estimated that the incidence of poverty decreased significantly between 1963-64 and 1971-72. Mujahid (1978) criticised the work done by the above two studies for ignoring the household size. He corrected the methodological error and analysed that during 1963-70 poverty levels increased in rural areas and declined in urban areas. Ahmad et al. (1989) defined four arbitrary poverty lines based on per capita expenditure for the years, 1976-77,1979 and 1984-85. He concluded that incidence of poverty and severity of poverty declined during the analysis period.

Under the minimum calorie requirement approach, poverty is defined in terms of a food poverty line which reflects the minimum food expenditure needed to achieve the minimum required level of caloric intake. Using this approach, Naseem (1977) found that compared to 1963-64, poverty declined in 1969-70 and it increased in 1971-72. Irfan and Amjad (1984) showed that rural poverty increased from 32 percent in 1963-64 to 43 percent in 1969-70 and declined to 29 percent in 1979. Cheema and Malik (1985) found a decline in rural poverty accompanied by a marginal increase in urban poverty both in terms of household and population during 1971-72 to 1979. Ercelawn (1990) estimated poverty at provincial levels in 1984-85. He found that 20 percent and 10 percent of the households were poor in the rural and urban areas of Pakistan respectively. The highest incidence of poverty was found in rural Balochistan followed by rural Punjab and rural Sindh. Havinga et al. (1990) showed that in 1984-85, about 40 percent households were poor and the average income of the poor was 25 percent below the poverty line. Malik (1996) estimated that poverty at the national level and in rural and urban areas, declined between 1984-85 and 1987-88, it then marginally increased between 1987-88 and 1990-91. 
Shirazi (1993) estimated poverty lines both in terms of income and expenditure based on nutritional needs. The FGT Poverty measures have been applied to HIES micro data to determine the incidence, intensity and severity of poverty in Pakistan. The analysis is carried out both on household and individual level and also on the regional level. The ratios of the very poor and the extremely poor have been determined by defining the very poor who can meet 80 percent of their requirement and extremely poor who can meet barely 70 percent of their needs. A detailed socioeconomic profile has been developed. He has analysed the possible role of INFAQ in the alleviation of poverty. He concluded that the poverty gap can be reduced by 4.61 percent and severity of poverty by 6.6 percent in overall Pakistan under the impact of INFAQ.

The basic needs approach is defined as the cost of the minimum bundle of basic needs consisting of food, clothing, housing, medical, education and other needs. Using this approach, Malik (1988) estimated poverty lines for rural and urban areas on the basis of food and non-food expenditure for certain years of the period from 1963-64 to 1984-85. His analysis showed that incidence of poverty increased during the 1960s and then declined at the end of 1970s and at the middle of 1980s. Ali (1995) used more scientific technique of Extended Linear Expenditure System (ELES) for estimating food poverty and total poverty in 1990-91. He suggested that 47 percent population had an income less than the estimated total poverty line, while the population below the food poverty line was only 10 percent. The World Bank (1995) presented the analysis of poverty trends in Pakistan from 1985 to 1990 and a detailed strategy for poverty reduction. According to the report, both the head-count ratio and the poverty gap ratio showed a reduction from 1984-85 to 1990-91. Jafri and Khattak (1995) computed four national poverty lines each for 1985-86, 1986-87, 1987-88 and 1990-91. The estimates of the head-count ratio, income gap ratio and FGT measures indicate that incidence of poverty decreased during 1986-87 and 1987-88 while the income gap ratio and FGT index showed that poverty increased significantly during 1987-88 and 1990-91.

The subjective approach determines the poverty lines on the bases of how people perceive poverty. Applying this approach, Ahmed (1993) estimated poverty lines for rural and urban areas based on an explicit listing of cost of meeting basic needs. The analysis confirmed an unambiguous reduction in poverty between 198485 and 1987-88, as well as a continuing trend till 1990-91. Gazdar et al. (1994) suggested various modifications to Ahmed's (1993) poverty lines. This study confirmed a declining trend in poverty between 1984-85 and 1987-88 at all levels and a continuing, though much less, decline, till 1990-91. The incidence of poverty was greater in large households and a strong negative association was also observed between poverty and asset holdings.

${ }^{1} I N F A Q$ is defined to include all Zakat, Ushr, Sadaqat, gifts and other assistance transfers to the poor. 
The relative poverty approach is used to high-light the income inequality. Using this approach, Akhtar (1988) calculated the head-count index, poverty gap and Sen's index in terms of per capita expenditure. She found concentration of the poor in Sindh followed by Punjab. She found that the relatively poor population was 35.5 percent at the national level, 35.2 percent and 36.1 percent at urban and rural levels respectively. Zaidi (1992) used 75 percent of national average equivalent expenditure and income as cut-off points for the year 1984-85. He estimated that 38.7 percent of the poor households were poor when poverty line was used in terms of average equivalent expenditure, while in case of average equivalent income, the proportion was 43 percent. At the provincial level, poverty in Balochistan was more pronounced. Zaidi and de Vos (1993) argued that starvation and hunger were no longer a common phenomenon in Pakistan. They operationalised the concept of poverty by using poverty lines which were defined as a certain percentage of the national average. They also used expenditures to measure household resources and the application of the adult equivalence scale. They found that in 1987-88 the households whose heads had less than primary education, rural households and households living in Punjab were not only relatively often poor, but poverty in those households was also more severe. Anwar (1997) estimated relative poverty at three cut-off points of 50 percent, 66.6 percent and 75 percent of national average equivalent expenditure. He suggested that 14.7 percent, 39.2 percent and 48.2 percent of all households were poor in 1987-88.

Human Poverty Index (HPI) brings together in one composite index deprivation in four basic dimensions of human life which includes a long and healthy life, knowledge, economic provisions and social inclusion. According to this index 47 percent population was poor in 1995. Poverty of Opportunity Index (POPI) is a composite of deprivations in three vital dimensions: health, education and income. According to this approach 44 percent people were poor in 1995 [MHCHD/UNDP (1999)].

The general pattern that emerges from a review of these earlier studies is that the magnitude of poverty is very sensitive to the choice of the poverty line as regards the trends. It is also concluded that incidence of poverty is higher in 1969-70 as compared to 1963-64. During 1970s, poverty levels declined in all areas and that trend continued till 1987-88. The year 1990-91 indicated a slight turning around of this trend of declining poverty.

\section{METHODOLOGY}

In Pakistan, like most of the other developing countries, a significant section of the population is still living below subsistence level. This study therefore focuses on absolute deprivation instead of relative deprivation. Poverty analysis involves three choices: choice of a suitable welfare indicator, choice of a poverty line and choice of a poverty measure. In this study total consumption expenditure is used as a welfare indicator. For a suitable poverty line, Ali's (1995) poverty lines based on basic needs are adopted which are estimated by using Extended Linear Expenditure 
System (ELES). The cut-off points below which an individual is considered to be poor are per month expenditure of Rs 270 for 1987-88 and Rs 374 for 1990-91. To control the value judgment in the selection of poverty measure, Foster, Greer and Thorbecke (1984) class of additively decomposable poverty measures are chosen. The description is as follow:

If per capita monthly expenditures are arranged in an ascending order,

$$
\begin{aligned}
& Y_{1} \leq Y_{2} \leq Y_{3 \ldots} \leq Y_{q}<Z<Y_{q+1 \ldots} \leq Y_{n} \\
& P_{\propto}=1 / n \sum_{i=1}^{q}\left\{\left(Z-Y_{i}\right) / Z\right\}^{\propto}
\end{aligned}
$$

Where,

$P_{\propto}=$ The FGT poverty measure.

The parameter $\propto$ can be viewed as a measure of poverty aversion.

$n=$ Total number of individuals.

$q=$ Total number of individuals having monthly expenditure below poverty line.

$Y_{i}=$ monthly expenditure of an individual.

$Z=$ Poverty line.

For $\propto=0$, the FGT poverty measure becomes, $P_{0=} q / n$. It is simply the headcount ratio, the proportion of individuals below poverty line.

For $\propto=1$, the FGT measure becomes poverty gap index:

$$
P_{1}=1 / n \sum_{i=1}^{q}\left\{\left(Z-Y_{i}\right) / Z\right\}
$$

The "poverty gap" indicator takes into account the expenditure of the poor and its distance from the poverty-line. It is sensitive to the number of poor and the extent of poverty. Kakwani (1990) noted that "If the degree of misery suffered by an individual is proportional to the income shortfall of that individual from the poverty, then the sum total of these shortfalls may be considered an adequate measure of poverty". But $P_{1}$ does not reflect change in the degree of severity of poverty, if income distribution among the poor becomes more unequal with mean income remaining unchanged.

For $\propto=2$. FGT measure is sensitive to the distribution of income within the poor. In $P_{2}$, expenditure shortfall to the poverty line is weighted by shortfall itself, where in $P_{1}$ these deficits are given equal weights. This satisfies the Sen's (1976) transfer axiom, in addition to monotonicity axiom, which states that if a transfer of income takes place from poor person to someone who is poorer, measured poverty should be decreased. Exploiting the additively separable property ${ }^{2}$ of (FGT) poverty

${ }^{2}$ Additively separable property implies that aggregate poverty measure is a weighted average of the measure of all subgroups of the population. If any subgroup becomes poorer, aggregate poverty will also increase, citrus paribus. 
measure, Ravallion and Huppi (1991) proposed the following simple decomposition formula.

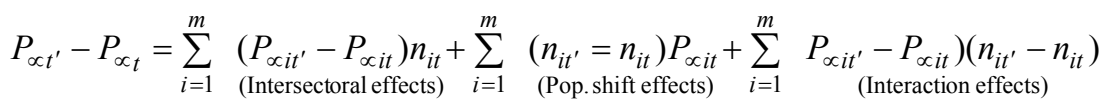

Where,

$$
\begin{aligned}
P_{i t} & =\text { The FGT poverty measure for sector ' } i \text { ' at time } t \\
n_{i t} & =\text { Population share of sector ' } i \text { ' at time ' } t \text { '. } \\
i & =\text { a given sector, where there are ' } m \text { ' such sectors }\left({ }_{i=1,2,3 \ldots \mathrm{m}}\right) . \\
t & =1987-88 . \\
t^{\prime} & =1990-91 .
\end{aligned}
$$

Intrasectoral effects represent the effect of sectoral growth on poverty, controlling for their base period population share. Population shift effects tell about poverty changes due to changes in population share of sectors between two periods. Interaction effects show the possible correlation between sectoral gain, population share and other factors, e.g changes in income distribution. As poverty measures are estimated from sample observations and usually involve a comparison among different time periods, socio-economic groups and countries, it becomes necessary to test the statistical significance of the observed differences.

The following methodology proposed by Kakwani (1990) will be used to test the statistical significance of the observed changes in sectoral poverty:

$$
t=\frac{P_{\propto i t}-P_{\propto i t^{\prime}}}{S E\left(P_{\propto i t}-P_{\propto i t^{\prime}}\right.}
$$

where,

$P_{\propto i t}=$ FGT poverty measure for sector ' $i$ ' in 1987-88, where ' $\propto$ ' ranges from 0 to 2.

$P_{\propto i t}=$ FGT poverty measure for sector ' $i$ ' in 1990-91, where ' $\propto$ ' ranges from 0 to 2.

$$
\begin{aligned}
& \operatorname{SE}\left(P_{\propto i t-} P_{\propto i t^{\prime}}\right)=\text { Standard error of }\left(\mathrm{P}_{\propto i \mathrm{it}}-\mathrm{P}_{\propto \mathrm{it}}\right) \text {, which is calculated as: } \\
& \operatorname{SE}\left(P_{\propto i t-} P_{\propto i t^{\prime}}\right)=\sqrt{ } \sigma_{\propto i t}^{2} / \mathrm{n}_{i t+} \sigma^{2}{ }_{\propto i t^{\prime}} / \mathrm{n}_{i t^{\prime}} \quad \text { where, } \\
& \sigma^{2} \propto i t=P_{(2 \propto) i t}-P_{\propto i t}^{2} \quad \sigma_{0 i t}^{2}=P_{0 i t}-P_{0 i t}^{2} \quad \sigma_{1 i t}^{2}=P_{2 i t}-P_{1 i t}^{2} \quad \sigma_{2 i t}^{2}=P_{4 i t}-P_{2 i t}^{2}
\end{aligned}
$$

$n_{i t}=$ Sample share of sector ' $i$ ' in period $t$, where $t$ is $1987-88$ and $t$ ' is $1990-91$.

$\propto=$ is power used in FGT measure and takes the value of 0,1 and 2 .

$' i$ ' $=$ is a given sector ranges from 0 to 9 .

\section{Data}

This study is based on the micro data of Household Income and Expenditure Survey (HIES) for 1987-88 and Household Integrated Economic Survey (HIES) 1990-91. HIES data are quite comprehensive and representative as they are based on 
an intensively probing questionnaire and a considerably large sample size. Since the unit of account of HIES is a household, in case of more than one earner in a household and belonging to different industries, it is not easy to determine the industry at the household level. As 50 percent earners are the heads of the households, we have taken the industry of the head of household as a proxy for the industry of the household as a whole. In such cases where the head of the household are not found economically active, the industry of the next earning member is taken as a proxy for industry of the household. Despite the above mentioned limitations, 'HIES' data sets are the best available source to analyse incidence of poverty in Pakistan.

To analyse sector-wise poverty, the economy has been disaggregated into the following nine traditional sectors:

(1) Agriculture, Hunting, Forestry and Fishing.

(2) Mining and Quarrying.

(3) Manufacturing.

(4) Electricity, Gas and Water.

(5) Construction.

(6) Wholesale and Retail Trade and Restaurants and Hotels.

(7) Transport, Storage and Communication.

(8) Financing, Insurance, Real Estate and Business Services.

(9) Community, Social and Personal Services.

\section{EMPIRICAL ANALYSIS}

Table 1 provides the information regarding real per capita monthly income and that of expenditure and the distribution of population across different sectors of the economy. The table shows that although overall monthly per capita income and expenditure increased but they decreased in six out of nine sectors. The highest per capita income and expenditure were registered among the households whose heads were employed in finance, insurance and business services while the construction sector was found on the opposite end in both the reference periods. Sectoral distribution of population showed that the agriculture sector has the largest population share followed by trade and community and social services sectors. Mining and quarrying sector has the lowest share in population.

The results presented in Table 2 are based on Ali's (1995) poverty lines who estimated per capita per month expenditure of Rs 270 for 1987-88 and Rs 374 for 1990-91 as a threshold levels. According to these results, almost half of the population is living below the poverty line in 1990-91. The highest incidence of poverty is found in Construction sector. A population shift from agriculture sector mitigates its influence on overall poverty. In this sector, population shift effects and interaction 
Table 1

Summary Data on Sectors of Employment

\begin{tabular}{|c|c|c|c|c|c|c|}
\hline \multirow[b]{2}{*}{ Industry } & \multicolumn{2}{|c|}{ Income $(\mathrm{Rs})^{*}$} & \multicolumn{2}{|c|}{ Expenditure (Rs)* } & \multicolumn{2}{|c|}{ Population (\%) } \\
\hline & $1987-88$ & $1990-91$ & $1987-88$ & $1990-91$ & $1987-88$ & $1990-91$ \\
\hline Agriculture & 328.17 & 452.64 & 317.34 & 353.67 & 41.65 & 36.31 \\
\hline Mining and Quarrying & 418.36 & 474.81 & 363.08 & 486.00 & .14 & 0.41 \\
\hline Manufacturing & 385.52 & 354.65 & 366.75 & 354.980 & 12.75 & 12.91 \\
\hline Electricity, Gas and Water & 464.46 & 454.43 & 430.58 & 452.81 & .77 & 1.22 \\
\hline Construction & 306.83 & 285.56 & 297.99 & 295.14 & 8.55 & 8.60 \\
\hline Trade & 401.92 & 382.19 & 383.51 & 367.57 & 15.12 & 15.56 \\
\hline Transport, Communication & 394.58 & 362.41 & 375.42 & 343.78 & 6.62 & 6.82 \\
\hline Finance and Insurance & 868.42 & 664.05 & 718.43 & 643.02 & 0.77 & 1.45 \\
\hline Community, Service & 458.42 & 385.43 & 416.49 & 378.19 & 13.27 & 16.71 \\
\hline Overall & 381.83 & 400.46 & 353.17 & 360.3 & 100.00 & 100.00 \\
\hline
\end{tabular}

Source: Based on HIES data.

* Per capita per month.

Table 2

Sectoral Structural of Poverty in Pakistan (Based on Ali(1995) Poverty Lines)

\begin{tabular}{|c|c|c|c|c|c|c|}
\hline \multirow[b]{2}{*}{ Industry } & \multicolumn{2}{|c|}{ Head-count Index } & \multirow[b]{2}{*}{ T Test } & \multirow{2}{*}{$\begin{array}{l}\text { Intrasectoral } \\
\text { Effects }\end{array}$} & \multirow{2}{*}{$\begin{array}{l}\text { Population } \\
\text { Shift Effect }\end{array}$} & \multirow{2}{*}{$\begin{array}{l}\text { Interaction } \\
\text { Effects }\end{array}$} \\
\hline & $1987-88$ & $1990-91$ & & & & \\
\hline Agriculture & 48.77 & 49.46 & 0.57 & 14.36 & -129.56 & -1.84 \\
\hline Mining and Quarrying & 36.93 & 52.90 & 1.32 & 1.10 & 4.99 & 2.16 \\
\hline Manufacturing & 45.39 & 48.38 & 1.44 & 18.93 & 3.75 & 0.25 \\
\hline \multicolumn{7}{|l|}{ Electricity, Gas and } \\
\hline Water & 31.81 & 35.01 & .53 & 1.22 & 7.20 & 0.7214 \\
\hline Construction & 59.26 & 61.49 & .92 & 9.47 & 1.50 & 0.06 \\
\hline Trade & 39.75 & 43.74 & 2.27 & 29.95 & 8.64 & 0.87 \\
\hline \multicolumn{7}{|l|}{ Transport, } \\
\hline Communication & 44.96 & 50.07 & 1.90 & 16.8 & 4.55 & 0.52 \\
\hline Finance and Insurance & 7.75 & 16.15 & 2.00 & 3.24 & 2.60 & 2.82 \\
\hline Community, Service & 40.24 & 44.48 & 2.50 & 28.00 & 68.72 & 7.24 \\
\hline Overall & 46.02 & 48.03 & 2.75 & 100.00 & & \\
\hline
\end{tabular}

effect helped in improving overall poverty situation hence the net affect of agriculture on overall poverty decreased. The highest change in head-count index in terms of percentage points has been observed in Mining and quarrying sector but this change is not statistically significant. The sector that suffered the most was Finance and insurance where the head-count index increased by more than 100 percent. The increasing trend of poverty incidence has been found in all the nine sectors.

Table 3 shows the per capita poverty gap index $P_{1 \text {, which reflects how far the poor }}$ are from the poverty line. It shows an overall increase in intensity of poverty, from 11.27 percent in 1987-88 to13.10 percent in 1990-91. All the sectors also show an increase in $P_{1}$. The values of $P_{1}$ range from 0.75 percent to 18.30 percent among different sectors of employment. The Construction sector, which had the highest proportion of poor, has also the highest rank by intensity of poverty whereas Finance and insurance has the lowest rank in poverty gap. Population shifts and interaction effects again helped in reducing the share of Agriculture sector in the increase of overall poverty gap. 
Table 3

Sector-wise Poverty Gap Index (Based on Ali (1995) Poverty Lines)

\begin{tabular}{|c|c|c|c|c|c|c|}
\hline \multirow[b]{2}{*}{ Industry } & \multicolumn{2}{|c|}{ Poverty Gap index } & \multirow[b]{2}{*}{ T Test } & \multirow{2}{*}{$\begin{array}{c}\text { Intrasectoral } \\
\text { Effects }\end{array}$} & \multirow{2}{*}{$\begin{array}{l}\text { Population } \\
\text { Shift Effect }\end{array}$} & \multirow{2}{*}{$\begin{array}{c}\text { Interaction } \\
\text { Effects }\end{array}$} \\
\hline & $1987-88$ & $1990-91$ & & & & \\
\hline Agriculture & 11.71 & 13.55 & 2.65 & 41.87 & -34.16 & -5.37 \\
\hline Mining and Quarrying & 7.78 & 16.40 & 2.34 & .65 & 1.15 & 1.28 \\
\hline Manufacturing & 11.50 & 13.11 & 2.21 & 11.20 & 1.04 & 0.15 \\
\hline Electricity, Gas and & & & & & & \\
\hline Water & 6.37 & 9.64 & 1.65 & 1.37 & 1.59 & 0.81 \\
\hline Construction & 16.68 & 18.30 & 1.68 & 7.68 & .46 & 0.05 \\
\hline Trade & 9.16 & 11.82 & 4.46 & 21.99 & 2.19 & 0.64 \\
\hline $\begin{array}{l}\text { Transport, } \\
\text { Communication }\end{array}$ & 10.89 & 13.37 & 2.64 & 8.95 & 1.21 & 0.28 \\
\hline Finance and Insurance & .75 & 4.52 & 2.94 & 1.60 & .28 & 1.39 \\
\hline Community, Service & 9.70 & 11.47 & 3.16 & 12.77 & 18.22 & 3.31 \\
\hline Overall & 11.27 & 13.10 & 7.20 & 100.46 & & \\
\hline
\end{tabular}

Table 4 shows the results of distributionally sensitive poverty measure, $P_{2}$. It also revealed the same pattern of sectoral poverty as was observed in Table 2 and 3 in 1987-88. Construction, Mining and Agriculture sectors have the highest income inequality among the poor in 1990-91. The results confirmed that Construction sector suffered the worst poverty by all dimensions i.e. incidence $\left(P_{0}\right)$, intensity $\left(P_{1}\right)$ and severity $\left(P_{2}\right)$ in both reference years. The Manufacturing sector is ranked second according to the severity of poverty criterion while it is third in case of incidence and intensity of poverty criterion.

All the three poverty measures show an increase in overall as well as sectorwise poverty between 1987-88 and 1990-91. The decomposition analysis of the observed that increased in poverty by all the three poverty measures show that more than 40 percent contribution was made by community and social service and trade sectors. The greater share of intrasectoral effect of Agriculture sector was offset by the strong population shift and interaction effects in all the three sectors. However, the results show a little variation in the ranking of these sectors by year as well as by measure of poverty.

Table 5 contains information regarding the distribution of poor across sectors. The highest concentration of poor is found in the Agriculture sector followed by Trade, Manufacturing and Construction sectors in 1987-88. In spite of the decline in the population share of Agriculture sector in 1990-91, it remained at the top. This table also presents the result of a location index which is derived by dividing the share of poor in each sector by the population share of that sector. A value of one hundred for this index shows an equal share. The higher the value of this indicator is from one hundred, the greater is the concentration of the poor relative to the population. According to this index, the highest concentration of the poor relative to the population share is found in Construction, followed by Agriculture, Manufacturing and Transportation. 
Table 4

Sector-wise FGT Index (Based on Ali (1995) Poverty Lines)

\begin{tabular}{|c|c|c|c|c|c|c|}
\hline Industry & \multicolumn{2}{|c|}{$\begin{array}{c}\text { Distributionally } \\
\text { Sensitivite Index }=\mathrm{P}_{2}\end{array}$} & T Test & $\begin{array}{l}\text { Intrasectoral } \\
\text { Effects }\end{array}$ & $\begin{array}{l}\text { Population } \\
\text { Shift Effect }\end{array}$ & $\begin{array}{c}\text { Interaction } \\
\text { Effects }\end{array}$ \\
\hline Agriculture & 3.94 & 5.09 & 2.48 & 46.37 & 20.42 & -5.95 \\
\hline Mining and Quarrying & 1.97 & 6.66 & 3.01 & 46.37 & 0.52 & 1.24 \\
\hline Manufacturing & 4.08 & 4.87 & 2.27 & 0.63 & 0.66 & 0.13 \\
\hline \multicolumn{7}{|l|}{ Electricity, Gas and } \\
\hline Water & 1.82 & 3.96 & 2.25 & 9.75 & 0.81 & .95 \\
\hline Construction & 6.23 & 7.31 & 2.09 & 1.59 & 0.31 & 0.05 \\
\hline Trade & 3.01 & 4.46 & 4.93 & 8.95 & 1.28 & 0.61 \\
\hline \multicolumn{7}{|l|}{ Transport, } \\
\hline Communication & 3.86 & 4.98 & 2.44 & 21.16 & 0.76 & 0.22 \\
\hline Finance and Insurance & .18 & 1.75 & 2.70 & 7.18 & 0.12 & 1.03 \\
\hline Community, Service & 3.37 & 4.05 & 2.63 & 1.18 & 11.24 & 2.27 \\
\hline Overall & 3.88 & 4.91 & 8.25 & 8.77 & & \\
\hline
\end{tabular}

Table 5

Sector-wise Distribution of Poor in Pakistan (Based on Ali (1995) Poverty Lines)

\begin{tabular}{lccccc}
\hline & \multicolumn{2}{c}{ Distribution of Poor } & & \multicolumn{2}{c}{ Location Index } \\
\cline { 2 - 3 } \cline { 5 - 6 } Industry & $1987-88$ & $1990-91$ & & $1987-88$ & $1990-91$ \\
\hline Agriculture & 44.30 & 37.40 & & 113.01 & 103.00 \\
Mining and Quarrying & .10 & 0.50 & & 76.92 & 121.95 \\
Manufacturing & 12.60 & 13.00 & & 105.00 & 100.70 \\
Electricity, Gas and Water & .50 & 0.90 & & 69.44 & 73.77 \\
Construction & 11.00 & 11.00 & & 136.65 & 127.91 \\
Trade & 13.10 & 14.20 & & 91.99 & 91.26 \\
Transport, Communication & 6.50 & 7.10 & & 104.33 & 104.11 \\
Finance and Insurance & .10 & 0.50 & & 13.70 & 34.48 \\
Community, Service & 11.60 & 15.50 & & 92.80 & 92.76 \\
\hline
\end{tabular}

\section{CONCLUSIONS}

This study attempts to examine the sectoral trends and patterns of poverty in Pakistan using HIES data for the years 1987-88 and 1990-91. The FGT(1984) class of additively decomposable poverty measure have been used to estimate the incidence, intensity and severity of poverty. The empirical evidence indicates that poverty has increased by all dimensions (incidence, intensity and severity) in almost all sectors during the period under considerations. There are also wide variations in the incidence of poverty among different sectors. Construction, Agriculture and Manufacturing are the badly affected sectors. The concentration index also indicates that the proportion of the poor relative to the proportion of the population is greater in these sectors. To check the reliability and validity of poverty estimates obtained from sample data, one should look at the behaviour of the macro variables. The results of this study are supported by similar trends of macroeconomic variables. The 
real per capita private consumption has been decreased during the reference periods by 5.15 percent. Real wages of construction workers decreased by more than 5 percent. Similarly, the share of wages in GDP has been decreased from 32.3 percent in 1987-88 to 30 percent in 1990-91. Moreover, a decline in the growth momentum, share of subsidies and public expenditure on basic social services in GDP, increase in rate of unemployment, rate of inflation and Gini coefficient are all in line with the evidence from the household survey. The support by the macroeconomic variables improves the reliability and validity of our result.

This study identifies the sectors, where the poor are concentrated. It also contributes to increase the understanding of the nature and extent of poverty in Pakistan. This study will be helpful for effective and well-targeted designing of strategies to reduced poverty.

\section{REFERENCES}

Ahmed, Ehtisham, and Stephen Ludlow (1989) Poverty, Inequality and Growth in Pakistan. The Pakistan Development Review 28:4 831-850.

Ahmed, M. (1993) Choice of a Norm of Poverty Threshold and Extent of Poverty in Pakistan. The Journal of Development Studies 12:2.

Akhtar, Shamshad (1988) Poverty in Pakistan. World Bank, Islamabad. (Draft Mimeographed.)

Ali, M. Shaukat (1995) Poverty Assessment: Pakistan's Case. The Pakistan Development Review 34:1.

Allaudin, T. (1975) Mass Poverty in Pakistan. The Pakistan Development Review 15: 4.

Anwar, Tilat (1997) Incidence of Relative Poverty in Pakistan from Household Survey. Journal of Rural Development and Administration 24:2.

Cheema, Aftab Ahmad, and Mohammad Hussain Malik (1985) Changes in Consumption Patterns and Employment under Alternative Income Distribution. The Pakistan Development Review 24:1.

Ercelawn, Aly A. (1990) Absolute Poverty in Pakistan: Poverty Lines, Incidence, Intensity. Applied Economics Research Centre. University of Karachi, Karachi: (Draft Paper.)

Foster, James, Joel Greer, and Erik Thorbecke (1984) A Class of Decomposable Poverty Measures. Econometrica 52:3.

Gazadar, H., S. Howes, and Salman Zaidi (1994) Poverty in Pakistan: Measurement Trends and Patterns. STICERD, London School of Economics. Background paper for the Pakistan Poverty Assessment. (Mimeographed.)

Havinga, I. C., F. W. Haanappel, A. S. Louter, and W. A. van den Andel (1990) Poverty in Pakistan 1984-85. The Pakistan Development Review 48:4.

Irfan, Mohammad, and Rashid Amjad (1984) Poverty in Rural Pakistan. In A. R. Khan and Eddy Lee (eds) Poverty in Rural Asia. Bangkok: International Labour Office/Asian Employment Programme. 
Jafri, S. M. Younas, and A. Khattak (1995) Income Inequality and Poverty in Pakistan. The Pakistan Economic and Social Review 33:2.

Kakwani, Nank (1990) Testing for Significance of Poverty Difference: With Application to Cote d'Ivore. The World Bank, Washington, D. C. (LSMA Working Paper No. 26.)

Mahbub ul Haq Centre for Human Development (1999) The Profile of Poverty in Pakistan. Islamabad: United Nations Development Programme.

Mahmood, S., K. H. Sheikh, and T. Mahmood (1991) Food Poverty and its Causes in Pakistan. The Pakistan Development Review 30:4.

Malik, M. H. (1988) Some New Evidence on the Incidence of Poverty in Pakistan. The Pakistan Development Review 27:4.

Malik, Sohail J. (1996) Poverty in Pakistan: 1984-85, 1987-88 and 1990-91. International Food Policy Research Institute, Washington, D. C., July. (Mimeographed.)

Mujahid, G. B. (1978) A Note of Measurement of Poverty and Income Inequalities in Pakistan: Some Observations in Methodology. The Pakistan Development Review 17:3.

Naseem, S. M. (1973) Mass Poverty in Pakistan: Some Preliminary Finding. The Pakistan Development Review 13:4.

Naseem, S. M. (1977) Rural Poverty and Landless in Pakistan. In ILO Report on Poverty and Landlessness in Asia. Geneva: International Labour Office.

Pakistan, Government of (1987-88) Household Income and Expenditure Survey. Karachi: Federal Bureau of Statistics.

Pakistan, Government of (1990-91) Household Integrated Economic Survey. Karachi: Federal Bureau of Statistics.

Ravallion, Martin, and Monika Huppi (1991) Poverty and Under Nutrition in Indonesia during the 1980s. World Bank, Washington, D. C. (Policy Research Working Paper 286.)

Sen, A. K. (1976) Poverty: An Ordinal Approach to Measurement. Econometrica 91. Shirazi, Naseem Shah (1993) An Analysis of Pakistan's Poverty Problem and its Alleviation Through INFAQ. Unpublished Ph.D dissertation in Economics, International Islamic University, Islamabad.

World Bank (1995) Poverty Assessment. Washington, D. C.: South Asia Region.

Zaidi, M. Ashghar (1992) Relative Poverty in Pakistan: An Estimation from the Household Income and Expenditure Survey 1984-85. The Pakistan Development Review 31:4.

Zaidi, M. Ashghar, and de Vos Klaas (1993) Research on Poverty Statistics in Pakistan: Some Sensitivity Analysis. The Pakistan Development Review 32:4. 


\section{Comments}

This is one of the few papers focussed on Sectoral Analysis of Poverty. Concern for poverty has been expressed over the centuries by historians, sociologists and economists. Its causes have been identified in a variety of sources ranging from deficiencies in the administration of income support to injustice of the social and economic system. The eradication of poverty has been sought in the reform of social security systems to changes in the form of socioeconomic systems.

With reference to Pakistan, a number of studies have been made on this important topic where the FGT poverty measures are used to estimate relative contribution of various sectors of employment to aggregate poverty. The conclusion of this research is that poverty has risen in almost all the sectors of the economy during 1987-88 and 1990-91. Construction, agriculture and manufacturing are found to be the most severely affected sectors. The results of the present study are consistent with earlier studies and the general trend of other macroeconomic variables.

I have some general observations on the paper which may be considered in the revised paper.

1. Poverty is a multidimensional concept and its conceptualisation is greatly influenced by the social and economic environment. To capture the different aspects of poverty new indices such as Human Poverty Index (HPI) and Poverty of Opportunity Index (POPI) have recently been introduced in Pakistan. The authors do mention these measures but have not used them in their paper without giving any reason. They may accept or reject these Indices on merit. They may add a few lines about them in their revised paper.

2. The estimates of poverty in this paper are based on 1987-88 and 1990-91 HIES data sets. However, other studies [Jaffery (1991)] used the most recent data of 1992-93, 1993-94 and 1995-96. We expect the authors to extend their study by using the latest available data.

3. In the second paragraph, on page 863 the authors have rightly pointed out the limitation of the $P_{1}$ poverty gap Index as it does not reflect change in the degree of severity of poverty. But they contradict it while explaining Table 3 by arguing that "the construction sector, which had the highest proportion of poor, has also the highest rank by intensity of poverty", knowing very well that the intensity of poverty cannot be estimated by $P_{1}$. 
4. The authors have reported estimates in various Tables. However, they have not properly explained the results, particularly the results of Table 4 . The values of indices should also be mentioned.

At the end I congratulate the authors for their efforts and contributions.

International Islamic University,

\section{Nasim Shah Shirazi}

Islamabad. 